\title{
A Method to Improve the Embryogenesis Rate of Banana Somatic Cell Embryogenesis
}

\author{
Shenghe Chang1,2, Zhengjing Wư ${ }^{3}$, Wei Sun ${ }^{1,2}$, Fei Lin',2, Qi Zeng'3, Jingyi Zhang3, Lan Qiao3, \\ Haiyan Shu1,2* \\ ${ }^{1}$ Haikou Experimental Station, Chinese Academy of Tropical Agricultural Sciences, Haikou, China \\ ${ }^{2}$ The Key Lab of Hainan Banana Genetics and Breeding, Haikou, China \\ ${ }^{3}$ School of Forestry, Henan University of Science and Technology, Luoyang, China \\ Email: *shuhy@zzu.edu.cn
}

How to cite this paper: Chang, S.H., Wu, Z.J., Sun, W., Lin, F., Zeng, Q., Zhang, J.Y., Qiao, L. and Shu, H.Y. (2018) A Method to Improve the Embryogenesis Rate of Banana Somatic Cell Embryogenesis. American Journal of Plant Sciences, 9, 531-541. https://doi.org/10.4236/ajps.2018.93040

Received: December 30, 2017

Accepted: February 24, 2018

Published: February 27, 2018

Copyright (c) 2018 by authors and Scientific Research Publishing Inc. This work is licensed under the Creative Commons Attribution International License (CC BY 4.0).

http://creativecommons.org/licenses/by/4.0/ c) (i) Open Access

\begin{abstract}
Getting embryogenic callus is the first step for banana transformation. Enhancing embryonic-callus-rate is important for banana molecular breeding. In this paper, WIND1, an AP2/ERF transcription factor was added into the embryonic-callus-inducing medium with poly-Arg and nuclear localization signal (NLS). The embryogenic-callus-induced rate of the immature male florescence cultured on the media containing the recombinant protein Arg9-NLSWIND1 was significantly higher than that of the immature male florescence cultured on the control media. Medium containing $0.01 \%$ of the protein Arg9-NLS-WIND1 had the best effect for inducing the embryogenesis of the immature male inflorescence. On the medium containing $0.01 \%$ of the protein Arg9-NLS-WIND1, $11.5 \%$ of the immature male flowers can develop embryonic callus. On the medium containing Arg9-NLS-WIND1, the protein might be transferred into cytoplasm of the explants by endocytosis due to the interaction between the poly-Arg transduction domain and the plasma membrane. After it entered the nucleus guided by NLS and bind with the target DNA domain, the somatic cell embryogenesis reactions were initiated and the embryonic callus formed.
\end{abstract}

\section{Keywords}

Protein Transduction, Banana, Embryogenic Callus, WIND1

\section{Introduction}

Banana is an important crop and fruit in tropical and subtropical countries.

${ }^{*}$ Corresponding author. 
However, banana production is always hindered because of lacking good varieties. Breeding new banana varieties through transgenic method is inevitable [1]. However, although some papers about banana transformation had been published, the transgenic method for banana is still a tough work for many laboratories. The main reasons are 1) banana transformation needed embryogenic suspension cell as initial material due to the worrying about chimera, which required much banana embryogenic callus [2];2) The embryogenesis rate of banana somatic cells is very low according to the methods used now [3] [4]. Therefore, if banana embryogenesis rate can be improved significantly, banana transformation might become easier.

WOUND INDUCED DEDIFFERENTIATION 1 (WIND1) is an AP2/ERF transcription factor. It participates in the regulation of cell dedifferentiation in Arabidopsis [5]. After WIND1 was over-expressed in Arabidopsis, typical callus with disorganized mass of cells formed on the surface of leaves, roots and hypocotyls [5]. As a transcription factor, WIND1 acts as a key molecular switch to initiate wound response to the control of cell dedifferentiation [6]. If WIND1 can be over-expressed in banana plant, the embryogenic callus of banana might be induced easily. However, transferring foreign genes into banana genome is a hard work itself. If the foreign transcription factor itself can be transferred into the nucleus of banana cells directly and played roles, this problem might be resolved.

Transactivator of transcription (TAT) protein transcription domain (PTD) is a special 10 - 20 amino acid sequence derived from HIV TAT protein [7]. Once added into the culturing meida, TAT-fusion protein can rapidly enter the cells. Within cells, the TAT-fusion protein is either degraded or refolded by the cellular machinery into functional protein [8]. Most of the TAT PTD contained Arg and Lys, which have strong positive charge, that lead to that these amino acid sequences could bind with cell membrane and be transferred into cell quickly [9] [10]. Poly-Arg transduction domain is an artificial sequence according to the sequences of transduction domains found. Its transduction efficiency is higher than TAT PTD derived from HIV [11]. Experiments showed that it can be used to lead the foreign protein to transfer the cell membrane [12].

In this paper, the transcription factor gene WIND1 was linked with poly-Arg and a nuclear localization signal or sequence (NLS), which is an amino acid sequence that "tags" a protein for import into the cell nucleus by nuclear transport [13]. Typically, NLS consists of one or more short sequences of positively charged lysines or arginines exposed on the protein surface [14]. And then, the artificial sequence was over-expressed in bacteria and the recombinant protein was extracted and purified. After the purified protein was sterilized by passing filter membrane, it was added into the embryogenic-callus-induced media. It was found that the embryogenic-callus-induced rate of the banana immature male florescence on the media containing the recombinant foreign protein was significantly higher than those on the control media. This indicated that after the recombinant protein touched with the explant cells, poly-Arg transduction 
domain can lead the followed amino acids pass through the cell membrane. The NLS can lead the followed protein enter the nucleus. In the nucleus, the transcription factor WIND1 can bind with the target DNA sequence and the somatic cell's dedifferentiation responses were initiated and callus formed. According to our knowledge, this is the first paper that reported that transcription factor can be guided into nucleus of plant cells and can induce the embryogenesis response of plant somatic cells. This might play potential roles in the transformation of crops whose trangenic systems are hard to be constructed.

\section{Materials and Methods}

According to the sequence of Arabidopsis gene WIND1 (GenBank accession number: AF370152.1), poly-Arg [12] and NLS [15], the artificial sequence of Arg9-NLS-WIND1 was synthesized (Figure 1). According to the sequence of Arg9-NLS-WIND1, primer1 (CGTCGCCGTCGTCGCCGTGAAGAAGAAGAG GAAGGTGGCATGGCAGCTGCTATGAATTT) and primer 2 (CATCTCGAG CTAAGCTAGAATCGAATCCCAATC) were synthesized to amplify the artificial sequence. The amplified product was purified and inserted into the vector of pMD19-T and transformed into E. coli DH5 $\alpha$. The plasmid pMD19-T (Arg9-NLS-WIND1) was extracted from the bacteria. According to the sequence of the plasmid vector pET28a and Arg9-NLS-WIND1, primer 3 (CGCGGA TCCATGGGTCGCAAGAAACGTCGCCAACGTCGCCGTCCGCCTGCCGTC GCCGTCGTCGCCGT) was synthesized. Primer 3 and primer 2 were used to amplify Arg9-NLS-WIND1 using pMD19-T (Arg9-NLS-WIND1) as template. The PCR product was purified and digested with Bam HI and Xho I. The plasmid of pET28a was also digested with Bam HI and Xho I. The digested PCR product and digested pET28a were ligated using T4 DNA ligase at $4^{\circ} \mathrm{C}$ for 24 hours. The ligated mixture was transformed into E. coli Top10. The positive clones were amplified using primer 1 and primer 2. The clones from which the responding DNA band could be amplified using primer 1 and primer 2 were sequenced. Plasmids were extracted and transformed into E.coli Rosseta (DE3) using the standard heat shock method.

ATGGTACGTCGCCGTCGTCGCCGTCGTCGCCGTGAAGAAGAAGAGGAAGGTGGC atggcagctgctatgaatttgtacacttgtagcagatcgtttcaagactctggtggtgaactcatggacgcgcttgtaccttttatcaaaag cgtttccgattctccttcttcttcttctgcagcgtctgcgtctgcgtttcttcacccctctgcgttttctctccctcctctccceggttattacccg gattcaacgttcttgacccaaccgttttcatacgggtcggatcttcaacaaaccgggtcattaatcggactcaacaacctctcttcttctcag atccaccagatccagtctcagatccatcatcctcttcctccgacgcatcacaacaacaacaactctttctcgaatcttctcagaccaaagcc gttactgatgaagcaatctggagtcgctggatcttgtttcgcttacggttcaggtgttccttcgaagccgacgaagctttacagaggtgtga ggcaacgtcactggggaaaatgggtggctgagatccgtttgccgagaaatcggactcgtctctggcttgggacttttgacacggcggag gaagctgcgttggcctatgataaggcggcgtacaagctgcgcggcgatttcgcccggcttaacttccctaacctacgtcataacggatct cacatcggaggcgatttcggtgaatataaacctcttcactcctcagtcgacgctaagcttgaagctatttgtaaaagcatggcggagactc agaaacaggacaaatcgacgaaatcatcgaagaaacgtgagaagaaggtttcgtcgccagatctatcggagaaagtgaaggcggagg agaattcggtttcgatcggtggatctccaccggtgacggagtttgaagagtccaccgctggatcttcgccgttgtcggacttgacgttcgc tgacccggaggagccgccgcagtggaacgagacgttctcgttggagaagtatccgtcgtacgagatcgattgggattcgattctagct

Figure 1. The sequence of Arg9-NLS-WIND1. The capital letters underlined referred to the sequence of Arg9. The bold capital letters showed the sequence of NLS (nuclear localization signal). The lowercase letter referred to the sequence of WIND1. 
One transformed clone was cultured $\left(37^{\circ} \mathrm{C}, 200 \mathrm{rpm}\right)$ in $3 \mathrm{ml} \mathrm{LB}$ liquid medium containing $50 \mathrm{mg} / \mathrm{L}$ kanamycin overnight. $200 \mu \mathrm{l}$ of such cultures were transferred into $20 \mathrm{ml} \mathrm{LB}$ liquid medium containing $50 \mathrm{mg} / \mathrm{L}$ kanamycin and cultured until that the $\mathrm{OD}_{600}$ was between 0.6 and 0.8. IPTG was added until that the final concentration was $0.3 \mathrm{mmol} / \mathrm{L}$ or $1 \mathrm{mmol} / \mathrm{L}$. The transformed bacteria were cultured continually at $37^{\circ} \mathrm{C}$ and $200 \mathrm{rpm}$. After being cultured for $2 \mathrm{~h}, 4 \mathrm{~h}$, $6 \mathrm{~h}$, and $8 \mathrm{~h}, 1 \mathrm{ml}$ of the cultures was transferred into one 1-ml tube. To select the best condition for protein purification, the samples were centrafugated at $15000 \mathrm{rpm}$ for $10 \mathrm{~min}$. The supernatant was discarded and the pellet was suspended with $50 \mu \mathrm{l} 2 \times$ SDS-PAGE Loading Buffer. The mixture was boiled at $100^{\circ} \mathrm{C}$ for $10 \mathrm{~min}$ and centrifugated at $15000 \mathrm{rpm}$ for $10 \mathrm{~min}$. The supernatant was injected and seperated in SDS-PAGE gel (4\% dense gel and 10\% seperation gel) at $120 \mathrm{~V}$ for $2.5 \mathrm{~h}$. For purifying the recombinant protein, $100 \mathrm{ml}$ of the bacterial cultures induced by IPTG were centrifugated at $9500 \mathrm{rpm}$ for $10 \mathrm{~min}$. The supernatant was discarded and the pellet was resuspended with $10 \mathrm{ml}$ Ni-Native0 solution ( $50 \mathrm{mmol} / \mathrm{L} \mathrm{NaH}_{2} \mathrm{PO}_{4}, 300 \mathrm{mmol} / \mathrm{L} \mathrm{NaCl}, \mathrm{pH}$.0). The bacterial cells were lysed by ultrosonification for $20 \mathrm{~min}$ (ultrosonification $5 \mathrm{~s}$, interval $5 \mathrm{~s}$ ). The mixture was centrifugated $\left(9500 \mathrm{rpm}, 4^{\circ} \mathrm{C}, 30 \mathrm{~min}\right)$. The supernatant and the pellet was electrophoresed in SDS-PAGE gel (4\% dense gel and $10 \%$ seperation gel) respectively. A Ni-NTA affinity column (Sangon Biotech, Shanghai, China) was loaded with ten volumes of Ni-Native0 solution. And then, the mixture containing the recombinant protein was loaded into the column and the flow velocity was $0.5 \mathrm{ml} / \mathrm{min}$. After the column was washed with ten volume of Ni-Native0 solution and Ni-Native50 solution $(50 \mathrm{mmol} / \mathrm{L}$ $\mathrm{NaH}_{2} \mathrm{PO}_{4}, 300 \mathrm{mmol} / \mathrm{L} \mathrm{NaCl}, 50 \mathrm{mmol} / \mathrm{L}$ Imidazole, $\mathrm{pH}$ 8.0) respectively, the recombinant protein was eluted by five volume of Ni-Native-250 $(50 \mathrm{mmol} / \mathrm{L}$ $\mathrm{NaH}_{2} \mathrm{PO}_{4}, 300 \mathrm{mmol} / \mathrm{L} \mathrm{NaCl}, 250 \mathrm{mmol} / \mathrm{L}$ Imidazole, $\mathrm{pH}$ 8.0) and five volume of Ni-Native-500 (50 mmol/L NaH ${ }_{2} \mathrm{PO}_{4}, 300 \mathrm{mmol} / \mathrm{L} \mathrm{NaCl}, 500 \mathrm{mmol} / \mathrm{L}$ Imidazole, pH 8.0;) respectively. The flow velocity was $1 \mathrm{ml} / \mathrm{min}$. The elution was collected and dialyzed in phosphate buffer. For collecting the recombinant protein in the insoluble fraction, the ultrosonified mixture was centrifugated and the supernatant was discarded. The pellet was resuspended with $5 \mathrm{ml} \mathrm{Ni-Denature-GuHCl}$ (100 mmol/L NaH $\mathrm{PO}_{4}, 300 \mathrm{mmol} / \mathrm{L} \mathrm{NaCl}, 6 \mathrm{~mol} / \mathrm{L} \mathrm{GuHCl}$, pH8.0). The mixture was centrifugated once again and the supernatant was transferred into a microtube. A Ni-NTA affinity column was loaded with ten volumes of Ni-Denature-Urea solution ( $100 \mathrm{mmol} / \mathrm{L} \mathrm{NaH} \mathrm{PO}_{4}, 300 \mathrm{mmol} / \mathrm{L} \mathrm{NaCl}, 8 \mathrm{~mol} / \mathrm{L}$ urea, $\mathrm{pH} 8.0$ ). And then, the supernant containing the recombinant protein was loaded into the column. The flow velocity was $0.5 \mathrm{ml} / \mathrm{min}$. After the column was washed with ten volumes of Ni-Denature-Urea solution, five volumes of $\mathrm{Ni}$-Denature-250 (100 mmol/L NaH${ }_{2} \mathrm{PO}_{4}, 300 \mathrm{mmol} / \mathrm{L} \mathrm{NaCl}, 8 \mathrm{~mol} / \mathrm{L}$ urea, 250 $\mathrm{mmol} / \mathrm{L}$ Imidazole, $\mathrm{pH}$ 8.0) was loaded into the column and the elution was collected. The flow velocity was $1 \mathrm{ml} / \mathrm{min}$. The elution was dialyzed and renatured in phosphate buffer. The protein content in the effluent was determined using a 
Bradford Protein Assay Kit (Tiandz, Beijing, China).

\section{Induction Banana Embryonic Callus on the Treated Medium}

Banana (Musa acuminate AAA Cavendish cv. Brazil) Male buds were collected one to ten weeks after flowering. The embryonic-callus-induced medium M2 was prepared as the following formula: $1 / 2 \mathrm{MS}+4 \mathrm{mg} / \mathrm{L} 2,4-\mathrm{D}+1 \mathrm{mg} / \mathrm{L} \mathrm{IAA}+$ $1 \mathrm{mg} / \mathrm{L} \mathrm{NAA}+1 \mathrm{mg} / \mathrm{L}$ Biotin $+30 \mathrm{~g} / \mathrm{L}$ Sucrose $+7 \mathrm{~g} / \mathrm{L}$ Agar $+30 \mathrm{mg} / \mathrm{l}$ ascorbic acid, pH5.8. After the medium was sterilized at high temperature, it was cooled to about $55^{\circ} \mathrm{C}$ in a superclean bench. Arg9-NLS-WIND1 effluent was filter-sterilized and added into the medium. The final concentration of Arg9-NLSWIND1 was $0.004 \%, 0.006 \%, 0.008 \%, 0.01 \%, 0.012 \%$ and $0.014 \%$, respectively. In a sterile hood, immature male flowers which localized from position 16 to 6 (1 being the immature flower closest to the meristematic dome) were isolated from the surface-sterilized buds and cultured on M2 medium. The cultures were kept in total darkness at $28^{\circ} \mathrm{C}$. Seven to nine mongths later, the embryonic callus induced was calculated and the rates of embryogenesis were assayed.

\section{Results}

1) The artificial sequence Arg9-NLS-WIND1 can be expressed in E. coli BL21(DE3) successfully.

After the artificial sequence Arg9-NLS-WIND1 (Figure 1) was synthesized, it was inserted into the vector pET28a and transformed into E. coli BL21(DE3) (Figure 2). The transformed bacterial cells were lysed and electrophoresed as described in material and methods. Since the length of WIND1 cDNA was $1 \mathrm{~kb}$. The DNA length of Arg9-NLS was $45 \mathrm{bp}$. The predicted length of Arg9-NLSWIND1 sequence was 352 amino acids. The supposed molecular weight of the protein Arg9-NLS-WIND1 should be $39 \mathrm{kD}$. When the transformed E. coli cells were cultured at $37^{\circ} \mathrm{C}$ and induced with $0.3 \mathrm{mmol} / \mathrm{L}$ or $1 \mathrm{mmol} / \mathrm{L}$ of IPTG, no corresponding protein band could be found in the 12\% SDS-PAGE gels after the

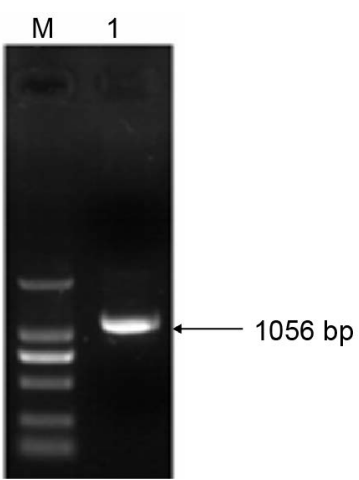

(a)

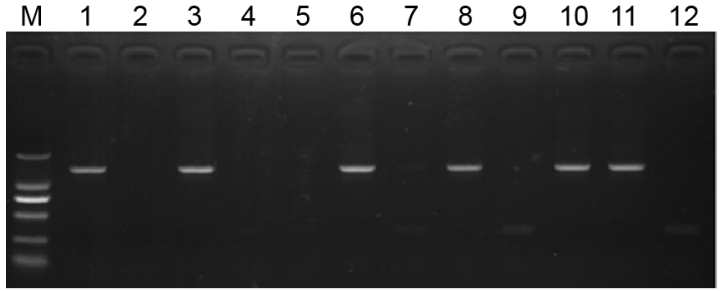

(b)

Figure 2. The artificial nucleotide Arg9-NLS-WIND1 was transformed into E. coli BL21(DE3). A: Arg9-NLS-WIND1 was amplified after it was synthesized. B: After Arg9-NLS-WIND1 was transformed into E. coli BL21(DE3), the positive clones were identified by PCR. M referred to the DNA ladder. 
lysed bacterial cells were electrophoresed. When the temperature was reduced to $30^{\circ} \mathrm{C}$, a remarked protein band whose molecular weight was $39 \mathrm{kD}$ was found (Figure 3 and Figure 4). This indicated that the artificial sequence could be expressed well at $30^{\circ} \mathrm{C}$.

2) The embryogenic-callus-induced rate of the immature male florescence cultured on the media containing the recombinant protein Arg9-NLS-WIND1 was significantly higher than that of the immature male florescence cultured on the control media.

Although immature male inflorescence is the best candidate for inducing embryogenic callus, the embryogenic-callus-induced rate is still very low. According to our experiment, the rate of embryogenic callus induced (Brazil) is only about 2.1\%. After the recombinant protein Arg9-NLS-WIND1 was filter-sterilized by passing through MILLIPORE membrane $(0.22 \mu \mathrm{m})$, it was added into the culturing media. Results showed that there was significantly more embryogenic callus induced from the immature male inflorescence cultured on

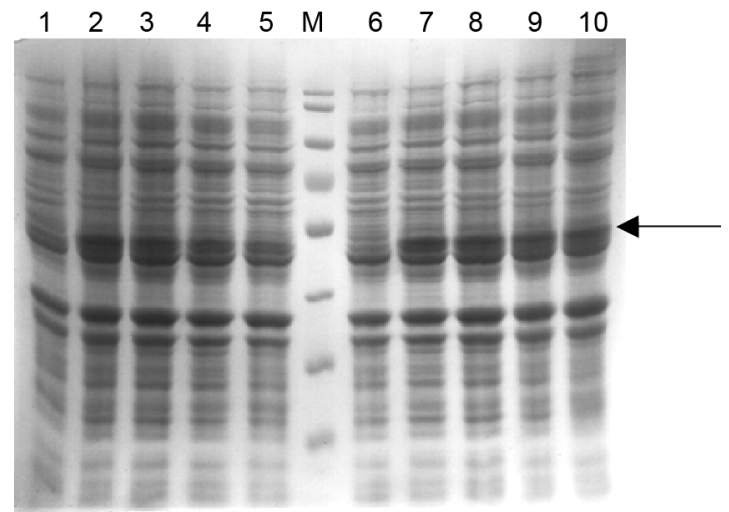

1: pET28a-AT1 $0.3 \mathrm{~mm}$ Oh

2: pET28a-AT1 $0.3 \mathrm{~mm} 2 \mathrm{~h}$

3: PET28a-AT1 $0.3 \mathrm{~mm} 4 \mathrm{~h}$

4: pET28a-AT1 $0.3 \mathrm{~mm} 6 \mathrm{~h}$

5: PET28a-AT1 $0.3 \mathrm{~mm} 8 \mathrm{~h}$

M: 170130957255433427

6: pET28a-AT1 $1 \mathrm{~mm} \mathrm{Oh}$

7: pET28a-AT1 $1 \mathrm{~mm} \mathrm{2h}$

8: $\mathrm{pET} 28 \mathrm{a}-\mathrm{AT} 1 \mathrm{~mm} 4 \mathrm{~h}$

9: pET28a-AT1 $1 \mathrm{~mm}$ 6h

10: pET28a-AT1 $1 \mathrm{~mm} 8 \mathrm{~h}$

Figure 3. E. coli BL21(DE3) harboring pET28a-AT1 was induced by $0.3 \mathrm{~mm} / 1 \mathrm{~mm}$ IPTG at $30^{\circ} \mathrm{C}$. After the bacteria were lysed, the whole bacterial bodies were separated in $12 \%$ SDS-PAGE.
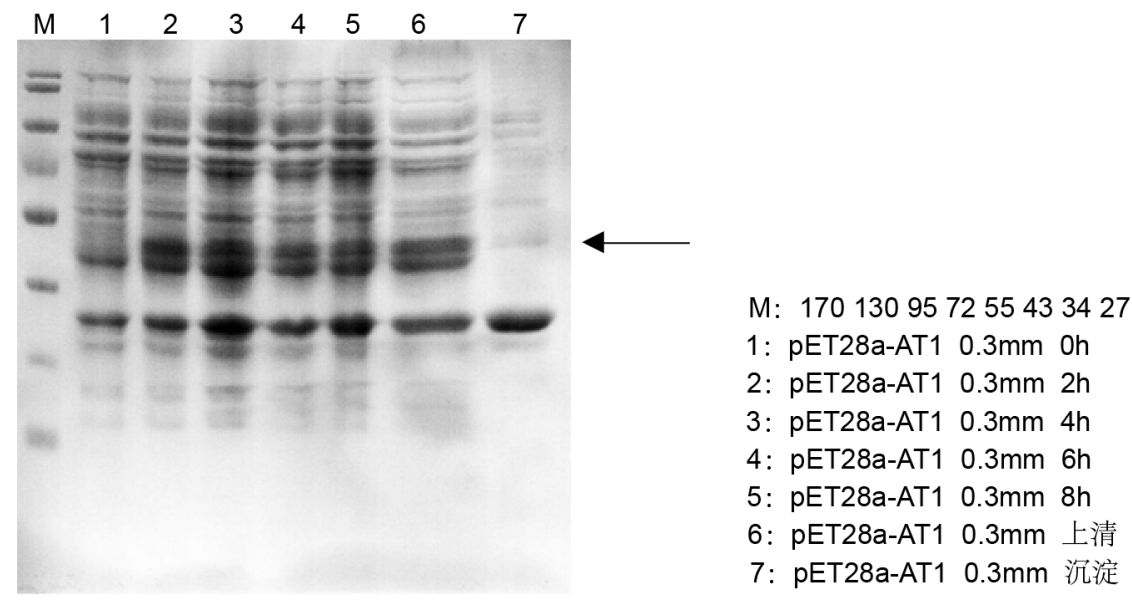

Figure 4. E. coli BL21(DE3) harboring pET28a-AT1 was induced by $0.3 \mathrm{~mm} / 1 \mathrm{~mm}$ IPTG at $30^{\circ} \mathrm{C}$. After the bacteria were lysed, the supernatant and the pellet was separated in $12 \%$ SDS-PAGE respectively. 
media containing the recombinant protein than those induced from the immature male inflorescence cultured on media without the artificial protein (Figure 5 and Figure 6). The embryogenic-callus-induced rate of the immature male florescence cultured on the media containing the protein Arg9-NLS-WIND1 was higher than that of the immature male florescence cultured on the control media. Adding the artificial protein Arg9-NLS-WIND1 can improve the embryogenic-callus-induced rate of the immature male florescence.

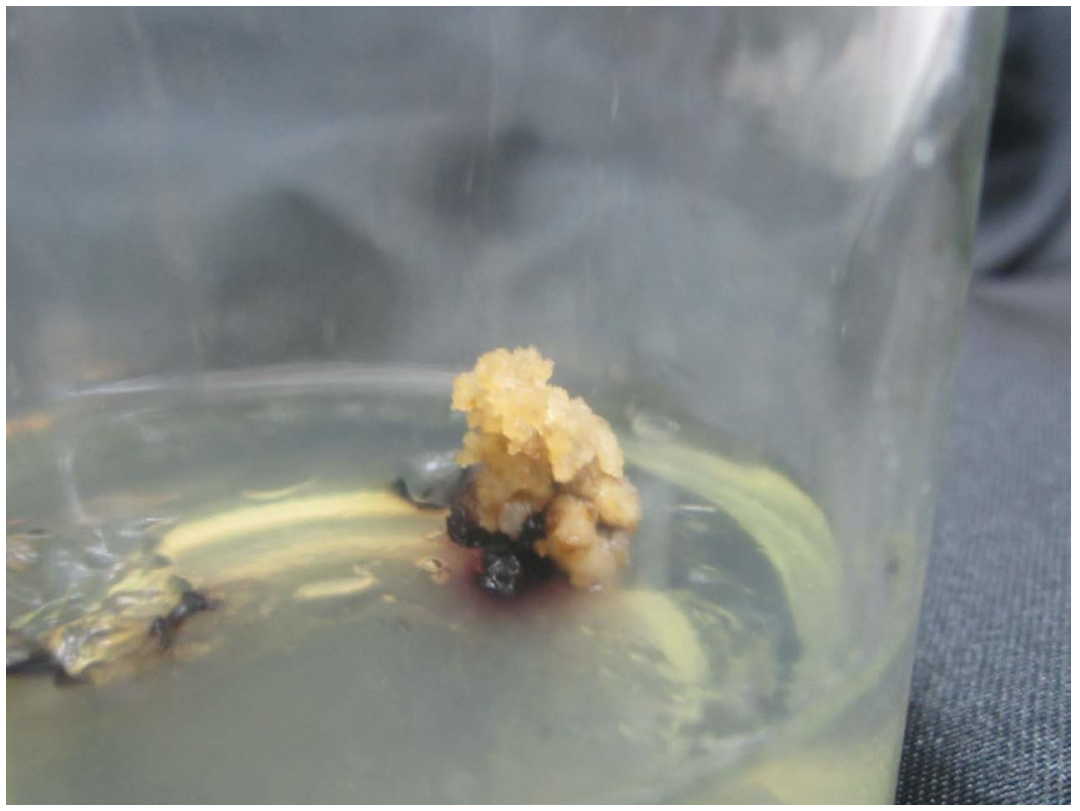

Figure 5. Embryogenic callus induced from imature male flower cultured on medium containing the recombinant protein Arg9-NLS-WIND1.

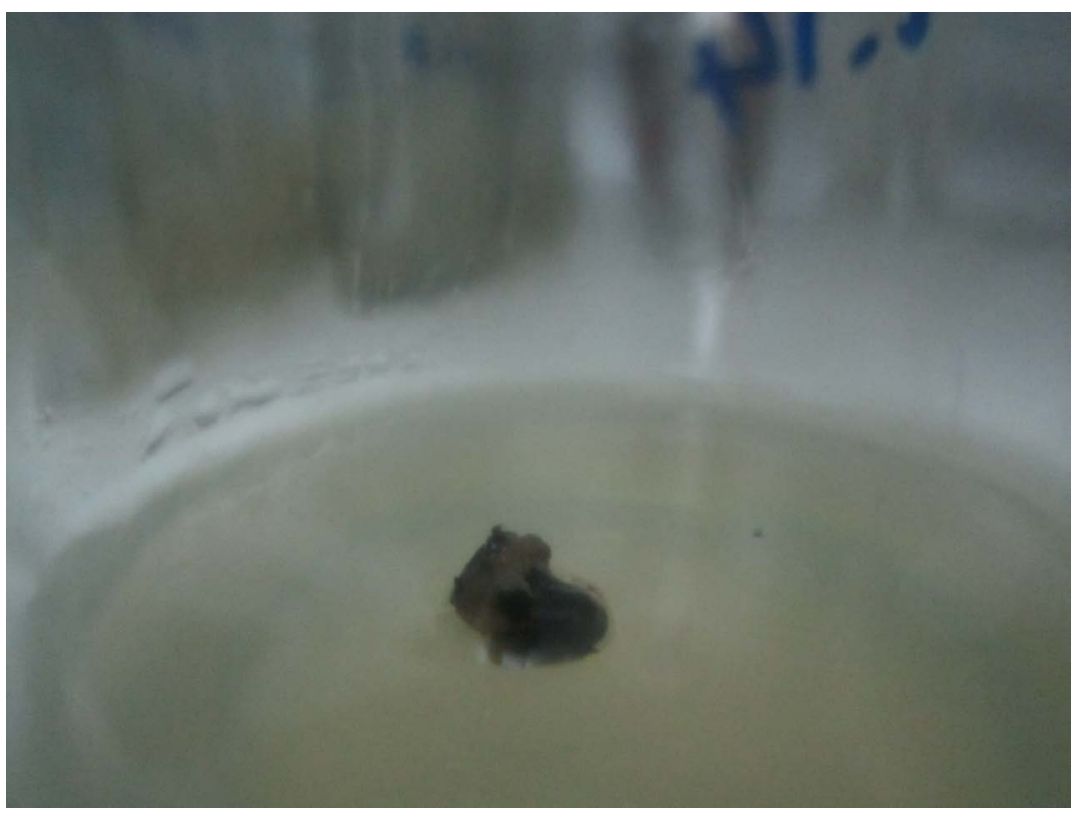

Figure 6. Immature male flower cultured on the medium without the recombinant protein Arg9-NLS-WIND1. 
3) Medium containing $0.01 \%$ of the protein Arg9-NLS-WIND1 had the best effect for inducing the embryogenesis of the immature male inflorescence.

After a series of the protein Arg9-NLS-WIND1 was added into the culturing media, immature male florescence was cultured on the media and put in darkness. Three months later, some crisp callus began to form. Results showed that the immature male florescence cultured on the media containing $0.01 \%$ of the protein Arg9-NLS-WIND1 formed the most embryogenic callus among the treatments. The embryogenic-callus-induced rate was about 10.2\% (Figure 7). The embryogenic-callus-induced rate of the immature male florescence cultured on the media containing more Arg9-NLS-WIND1 was less than that of the immature male florescence cultured on the media containing $0.01 \%$ of the protein Arg9-NLS-WIND1. This suggested that media containing $0.01 \%$ of the protein Arg9-NLS-WIND1 is the best treatment for enhancing the embryogenic-callusinduced rate of banana immature male florescence.

\section{Discussion}

Protein transduction referred to that some proteins were transferred into cells and play roles directly. Many researchers recognized protein transduction as a promising vehicle for delivery of macromolecular drugs [16]. It has been widely used in medical experiments [7] [17]. Some proteins with special roles have also been transferred into plant cells successfully [18] [19] [20] [21].

Protein transduction has been found when transactivator of HIV transcription (TAT-1) experiments was done. TAT- 1 is a protein composed of 86 amino acids, which binds to the transacting response element (TAR) of the viral RNA to transactivate the viral promoter. TAT-1 can be internalized into cells after it was added into the culture medium [22] [23]. Later, researchers found that not only

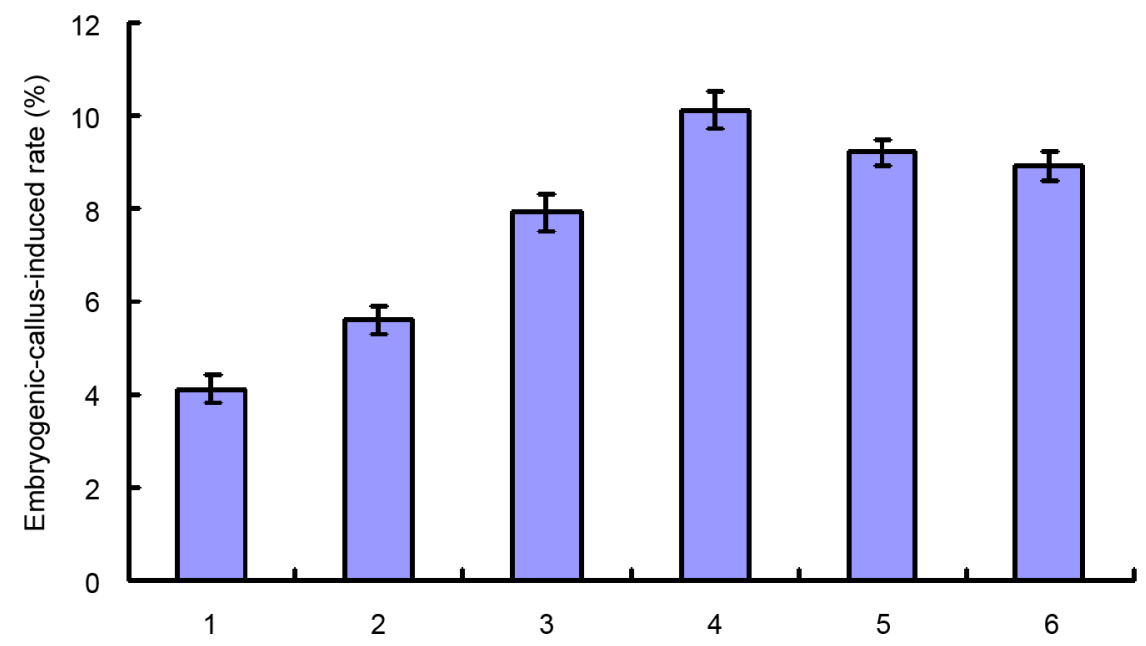

Figure 7. The embryogenic-callus-induced rates of the immature male flowers cultured on media containing different amount of Arg9-NLS-WIND1. 1 to 6 referred to the final concentration of Arg9-NLS-WIND1 in the medium was $0.004 \%, 0.006 \%, 0.008 \%, 0.01 \%$, $0.012 \%$ and $0.014 \%$ respectively. 
TAT peptide, but also various arginine-rich oligopeptides poses very similar characteristics in translocating proteins into cells [11].

The process of plasma membrane invagination in animal cells has also been found in plant cells [24] [25]. Poon et al. found that some specific Arabinogalactan proteins were isolated and incorporated into tissue culture medium, cotton somatic embryogenesis can be promoted [26]. This also indicated that exogenous proteins can be transformed into plant cells and play roles directly.

Banana transformation is a hard work for many laboratories. The important reason is that it is difficult to get embryogenic callus. If some proteins which can induce embryogenesis can be transferred into banana somatic cells directly and play roles, this hard work might become much easier. WIND1 is an important transcription factor that participated in plant somatic cell embryogenesis [5]. If WIND1 was over-expressed in Arabidopsis, there was much embryogenic callus can be found on the roots, hypocotyls and cotyledons of the transgenic plants [6]. Only over-expressing WIND1 is enough to induce and maintain the status of cell embryogenesis [5]. Excess expression of WIND1 might be the most important step for inducing plant somatic cell embryogenesis [6]. If WIND1 protein can be transferred into banana somatic cells, the embryogenic-callus-induced rate of banana somatic explants might be enhanced significantly.

Immature male florescence is the best candidate for inducing banana emnryogenic callus. However, on usual medium, the embryogenic-callus-induced rate of banana immature male florescence is only about 4.3\% [3] [4]. Considering the pollution from bacteria or fungi, this rate will become even lower. After the artificial protein Arg9-NLS-WIND1 was added into the medium, the embryogenic-callus-induced rate of banana immature male florescence was increased significantly. At descent dose, such as $0.01 \%$ of Arg9-NLS-WIND1, this rate can be enhanced to $11.5 \%$. This demonstrated that the artificial protein Arg9-NLS-WIND1 can improve banana somatic cell embryogenesis. This might be due to the following mechanism. After the protein was added into the culturing medium, it was transferred into cytoplasm because of endocytosis due to the interaction between the poly-Arg transduction domain and the plasma membrane [11]. In the cytoplasm, the protein was guided to pass through the nucleus pore by NLS and enter the nucleus, in which the protein bind with some specific DNA domain and the somatic cell embryogenesis reactions were initiated. Auxin production or its response was induced and embryogenic cells formed.

Altogether, in this paper, we found that after the artificial protein was added into the medium, the embryogenic-callus-induced rate of banana immature male florescence can be improved significantly. According to our knowledge, this is the first paper reported that banana somatic cell embryogenesis can be induced by adding artificial WIND1 protein into culturing medium. Considering the difficulties for banana transformation and the importance of banana production in many tropical and subtropical countries, this finding might play potential roles in banana breeding and banana production in the future. 


\section{Acknowledgements}

This work was supported by the Key Research and Developmental Plan Item of Hainan Province (No. ZDYF2017024), Ministry of Agriculture 948 Funding of China (No. 2015-Z21).

\section{References}

[1] Khanna, H., Paul, J., Harding, R., Dickman, M. and Dale, J. (2007) Inhibition of Agrobacterium-Induced Cell Death by Antiapoptotic Gene Expression Leads to Very High Transformation Efficiency of Banana. Molecular Plant-Microbe Interactions, 20, 1048-1054. https://doi.org/10.1094/MPMI-20-9-1048

[2] Huang, X., Huang, X.L., Xiao, W., Zhao, J.T., Dai, X.M., Chen, Y.F. and Li, X.J. (2007) Highly Efficient Agrobacterium-Mediated Transformation of Embryogenic Cell Suspensions of Musa acuminate cv. Mas (AA) via a Liquid Co-Cultivation System. Plant Cell Reports, 26, 1755-1762. https://doi.org/10.1007/s00299-007-0376-x

[3] Strosse, H., Domergue, R., Panis, B., Escalant, J. and Cote, F. (2001) Banana and Plantain Embryogenic Cell Suspensions. INIBAP Technical Guidelines, 8, 1-31 Montpellier Cedex, France.

[4] Cote, F.X., Domergue, R., Monmarson, S., Schwendiman, J., Teisson, C. and Escalant, J.V. (1996) Embryogenic Cell Suspensions from the Male Flower of Musa AAA cv. Grand nain. Physiologia Plantarum, 97, 285-290. https://doi.org/10.1034/j.1399-3054.1996.970211.x

[5] Iwase, A., Mitsuda, N., Koyama, T., Kojima, M. and Arai, T. (2011) The AP2/ERF Transcription Factor WIND1 Controls Cell Dedifferentiation in Arabidopsis. Current Biology, 21, 508-514. https://doi.org/10.1016/j.cub.2011.02.020

[6] Iwase, A., Ohme-Takagi, M. and Sugimoto, K. (2011b) WIND1, A Key Molecular Switch for Plant Cell Dedifferentiation. Plant Signaling \& Behavior, 6, 1943-1945. https://doi.org/10.4161/psb.6.12.18266

[7] Zhang, H., Ma, Y., Gu, J., Liao, B., Li, J., Wong, J. and Jin, Y. (2012) Reprogramming of Somatic Cells via TAT-Mediated Protein Transcription of Recombinant Factors. Biomaterials, 33, 5047-5055. https://doi.org/10.1016/j.biomaterials.2012.03.061

[8] Morris, M.C., Depollier, J., Mery, J., Heitz, F. and Divita, G. (2001) A Peptide Carrier for the Delivery of Biologically Active Proteins into Mammalian Cells. Nature Biotechnology, 19, 1173-1176. https://doi.org/10.1038/nbt1201-1173

[9] Deshayes, S., Plenat, T., Charnet, P., Divita, G., Molle, G. and Heitz, F. (2006) Formation of Transmembrane Ionic Channels of Primary Amphipathic Cell-Penetrating Peptides. Consequences on the Mechanism of Cell Penetration. Biochimica et Biophysica Acta, 1758, 1846-1851. https://doi.org/10.1016/j.bbamem.2006.08.010

[10] Henriques, S.T., Quintas, A. and Bagatolli, L.A. (2007) Energy Independent Translocation of Cell-Penetrating Peptides Occurs without Formation of Pores. A Biophysical Study with pep-1. Molecular Membrane Biology, 24, 282-293. https://doi.org/10.1080/09687860601142936

[11] Futaki, S. (2005) Membrane-Permeable Arginine-Rich Peptides and the Translocation Mechanisms. Advanced Drug Delivery Reviews, 57, 547-558. https://doi.org/10.1016/j.addr.2004.10.009

[12] Zhao, J., Xiao, W., Fu, W., Gao, P., Yuan, Q. and Liu, J. (2009) Prokaryotic Expression and Biological Activity of Poly-Arg Protein Transduction Domain-Apoptin Fusion Protein. Chin J Biologicals, 22, 448-451. 
[13] Lee, B.J., Cansizoglu, A.E., Süel, K.E., Louis, T.H., Zhang, Z. and Chook, Y.M. (2006) Rules for Nuclear Localisation Sequence Recognition by Karyopherin Beta 2. Cell, 126, 543-548. https://doi.org/10.1016/j.cell.2006.05.049

[14] Cansizoglu, A.E., Lee, B.J., Zhang, Z.C., Fontoura, B.M. and Chook, Y.M. (2007). Structure-Based Design of a Pathway-Specific Nuclear Import Inhibitor. Nature Structural \& Molecular Biology, 14, 452-454. https://doi.org/10.1038/nsmb1229

[15] Wu, G., Zhu, X., Liu, J., Dang, Y., Li, S. and Huang, P. (2004) TAT Peptide and Nuclear Localization Signal Mediated Protein Delivery into Cell Nuclei. China Biotechnology, 24, 61-63.

[16] Bae, H. and Lee, K. (2013) On Employing a Translationally Controlled Tumor Protein-Derived Protein Transduction Domain Analog for Transmucosal Delivery of Drugs. Journal of Controlled Release, 170, 358-364.

https://doi.org/10.1016/j.jconrel.2013.06.010

[17] Tachikawa, K., Schroder, O., Frey, G., Briggs, S.P. and Sera, T. (2004) Regulation of the Endogenous VEGF-A Gene by Exogenous Designed Regulatory Proteins. PNAS, 101, 15225-15230. https://doi.org/10.1073/pnas.0406473101

[18] Mae, M., Myrberg, H., Jiang, Y., Paves, H., Valkna, A. and Langel, U. (2005) Internalisation of Cell-Penetrating Peptides into Tobacco Protoplasts. Biochimica et Biophysica Acta, 1669, 101-107. https://doi.org/10.1016/j.bbamem.2005.01.006

[19] Zonin, E., Moscatiello, R., Miuzzo, M., Cavallarin, N., Paolo, M.L.D., Sandona, D., Marin, O., Brini, M., Negro, A. and Lorella Navazio, L. (2011) TAT-Mediated Aequorin Transduction: An Alternative Approach for Effective Calcium Measurements in Plant Cells. Plant Cell Physiology, 52, 2225-2235.

https://doi.org/10.1093/pcp/pcr145

[20] Qi, X., Droste, T. and Kao, C.C. (2011) Cell-Penetrating Peptides Derived from Viral Capsid Proteins. MPMI, 24, 25-36. https://doi.org/10.1094/MPMI-07-10-0147

[21] Chugh, A. and Eudes, F. (2007) Translocation and Nuclear Accumulation of Monomer and Dimer of HIV-1 Tat Basic Domain in Triticale Mesophyll Protoplasts. Biochimica et Biophysica Acta, 1768, 419-426. https://doi.org/10.1016/j.bbamem.2006.11.012

[22] Frankel, A.D. and Pabo, C.O. (1988) Cellular Uptake of the Tat Protein from Human Immunodeficiency Virus. Cell, 55, 1189-1193. https://doi.org/10.1016/0092-8674(88)90263-2

[23] Green, M. and Loewenstein, P.M. (1988) Autonomous Functional Domains of Chemically Synthesized Human Immunodeficiency Virus Tat Trans-Activator Protein. Cell, 55, 1179-1188. https://doi.org/10.1016/0092-8674(88)90262-0

[24] Ghugh, A. and Eudes, F. (2008) Cellular Uptake of Cell-Penetrating Peptides pVEC and Transportan in Plants. Journal of Peptide Science, 14, 477-481. https://doi.org/10.1002/psc.937

[25] Rosenbluh, J., Singh, S.K., Gafni, Y., Graessmann, A. and Loyter, A. (2004) Non-Endocytic Penetration of Core Histones into Petunia Protoplasts and Cultured Cells: A Novel Mechanism for the Introduction of Macromolecules into Plant Cells. Biochimica et Biophysica Acta, 1664, 230-240. https://doi.org/10.1016/j.bbamem.2004.06.003

[26] Poon, S., Heath, R.L. and Clarke, A.E. (2012) A Chimeric Arabinogalactan Protein Promotes Somatic Embryogenesis in Cotton Cell Culture. Plant Physiology, 160, 684-695. https://doi.org/10.1104/pp.112.203075 